\title{
Pengaruh Komunikasi Interpersonal Terhadap Prestasi Belajar Peserta Didik Kelas XI IPA di SMAN 1 Tanjung Mutiara Kabupaten Agam
}

\author{
Wike Karisma ${ }^{1}$, Septya Suarja ${ }^{2}$, Citra Imelda Usman ${ }^{3}$ \\ STKIP PGRI Sumatera Barat ${ }^{1}$ \\ Email: wikekarisma71@gmail.com \\ STKIP PGRI Sumatera Barat ${ }^{2}$ \\ Email: septya.suarja99@gmail.com \\ STKIP PGRI Sumatera Barat ${ }^{3}$ \\ Email: citraimelda08@gmail.com
}

\begin{abstract}
ABSTRAK
Penelitian ini bertujuan untuk mengetahui secara objektif tentang pengaruh komunikasi interpersonal terhadap prestasi belajar peserta didik kelas XI IPA di SMAN 1 Tanjung Mutiara Kabupaten Agam. Jenis penelitian yang digunakan adalah metode deskriptif kuantitatif. Populasi penelitian ini adalah peserta didik kelas XI IPA SMA N 1 Tanjung Mutiara Kabupaten Agam. Populasi dalam penelitian ini ada 134 peserta didik. Pengambilan sampel dalam penelitian ini menggunakan teknik proportional random sampling. Dari hasil perhitungan diperoleh sampel sebanyak 57 responden. Instrumen yang digunakan dalam penelitian ini adalah angket. Untuk menganalisis data digunakan rumus regresi linear sederhana guna untuk melihat pengaruh komunikasi interpersonal terhadap prestasi belajar peserta didik kelas XI IPA di SMAN 1 Tanjung Mutiara Kabupaten Agam. Hasil penelitian diperoleh: 1) Gambaran komunikasi interpersonal berada pada kategori baik 2) Gambaran prestasi belajar pada kategori sangat tinggi 3) Pengaruh komunikasi interpersonal terhadap prestasi belajar peserta didik berdasarkan uji regresi sebesar 0,119 $x 100 \%$ atau 11,9\%. Berdasarkan temuan penelitian ini peneliti merekomendasikan kepada peserta didik untuk dapat mempertahankan kemampuan komunikasi interpersonal serta meningkatkan prestasi belajar.
\end{abstract}

Kata Kunci: Komunikasi Interpersonal, Prestasi Belajar

\section{The Influence Of Interpersonal Comminication On The Learning Achievement Of Class XI Science Students At SMAN 1 Tanjung Mutiara, Agam Regency}

\begin{abstract}
This study aims to find out objectively about the effect of interpersonal communication on the learning achievement of class XI science students at SMAN 1 Tanjung Mutiara, Agam Regency. The type of research used is descriptive quantitative method. The population of this study were students of class XI IPA SMAN 1 Tanjung Mutiara, Agam Regency. The population in this study were 134 students. Sampling in this study using proportional random sampling technique. From the calculation results obtained a sample of 57 respondents. The instrument used in this research is a questionnaire. To analyze the data, a simple linear regression formula was used in order to see the effect of interpersonal communication on the learning achievement of class XI science students at SMAN 1
\end{abstract}


Tanjung Mutiara, Agam Regency. The results of the study obtained 1) The description of interpersonal communication is in the good category 2) The description of learning achievement in the very high category 3) The influence of interpersonal communication on the learning achievement of students based on the regression test is $0.199 \times 100 \%$ or $11.9 \%$. Based on the findings of this study, the researcher recommends that students be able to maintain interpersonal communication skills and improve learning achievement.

Keyword: Interpersonal Communication, Learning Achievement

\section{PENDAHULUAN}

Sebagai makhluk sosial remaja senantiasa berhubungan dengan orang-orang di sekitarnya agar dapat mengetahuhi dan mengenali lingkungannya. Untuk dapat mengetahui dan mengenali lingkungannya remaja tentu harus memiliki kemampuan dalam berkomunikasi. Salah satu kemampuan komunikasi yang harus dimiliki adalah kemampuan berkomunikasi secara interpersonal.

Devito (2011:252) menyatakan bahwa komunikasi interpersonal adalah proses penyampaian pesan dari komunikator kepada komunikan atau sekelompok komunikan dengan berbagai dampak dan peluang umpan balik segera dari komunikan. Dalam hal ini komunikator berperan sebagai narasumber pesan dan komunikan berperan sebagai penerima pesan yang segera memberikan umpan balik pada komunikator. Komunikasi interpersonal adalah komunkasi antara orang-orang secara tatap muka, yang memungkinkan setiap pesertanya menangkap reaksi orang lain secara verbal secara langsung baik secara verbal ataupun non verbal (Mulyana, 2000:73).

Karakteristik komunikasi interpersonal menurut Devito (2011:285) dalam komunikasi antarmanusia yaitu:

1. Keterbukaan, kemauan menanggapi dengan senang hati informasi yang diterima didalam menghadapi hubungan antar pribadi.

2. Empati, merasakan apa yang dirasakan orang lain.

3. Dukungan, situasi yang terbuka untuk mendukung komunikasi berlangsung secara efektif.

4. Rasa positif, seseorang harus memiliki perasaan positif terhadap dirinya, mendorong orang lain lebih lebih aktif berpartisipasi, dan menciptakan situasi komunikasi kondusif untuk interaksi yang efektif. 
5. Kesetaraan, pengakuan secara diam-diam bahwa kedua belah pihak menghargai, berguna, dan mempunyai sesuatu yang penting untuk disumbangkan.

Komunikasi interpersonal sangat mempengaruhi prestasi belajar, karna dalam proses belajar mengajar merupakan kegiatan interaksi yang berpangkal pada komunikasi. Dalam pembelajaran sangat diperlukan kemampuan komunikasi interpersonal agar memudahkan peserta didik untuk menguasai pembelajaran supaya prestasi belajar meningkat.

Menurut Poerwanto, 2007 (Hamdu, dkk, 2011:83) memberikan pengertian prestasi belajar yaitu hasil yang dicapai oleh seseorang dalam usaha belajar sebagaimana yang dinyatakan dalam lapor. Selanjutnya Hamdu, dkk (2011:83) mengatakan bahwa "Prestasi belajar adalah suatu bukti keberhasilan belajar atau kemampuan seseorang peserta didik dalam melakukan kegiatan belajar sesuai dengan bobot yang dicapainya”. Prestasi belajar adalah "Kesempurnaan yang dicapai seseorang dalam berfikir, merasa dan berbuat, prestasi belajar dikatakan sempurna apabila memenuhi tiga aspek yakni: kognitif, afektif, dan psikomotor, sebaliknya dikatakan prestasi kurang memuaskan jika seseorang belum mampu memenuhi target dalam ketiga kriteria tersebut".

Rendahnya prestasi belajar peserta didik di sekolah telah menjadi masalah nasional yang harus diperhatikan oleh berbagai kalangan. Ada banyak faktor yang mempengaruhi prestasi belajar peserta didik, salah satu diantaranya adalah komunikasi interpersonal sangat diperlukan setiap manusia agar lebih mudah bersosialisasi dengan lingkungan dimana ia berada. Sebagaimana yang diungkapkan Safari, 2005 (Fitria, 2014:2) bahwa kemampuan komunikasi interpersonal menjadi sangat penting karena pada dasarnya banyak kegiatan dalam hidup peserta didik yang terkait dengan orang lain.

Selanjutnya menurut Fitria (2014:2) kemampuan komunikasi interpersonal yang merupakan faktor internal juga mempengaruhi proses dan prestasi belajar peserta didik. Proses belajar mengajar akan senantiasa merupakan kegiatan interaksi yang berpangkal pada komunikasi yang berarti menjadikan milik bersama yakni peserta didik sebagai pihak yang belajar dan guru sebagai subjek pokoknya. Dalam hal ini kemampuan komunikasi interpersonal peserta didik akan tampak yaitu menunjukkan reaksi sosial yang berbedabeda. Ada peserta didik yang muda bergaul, ada pula peserta didik yang sulit untuk untuk bersosialisasi, kesulitan bersosialisasi dapat disebabkan oleh beberapa faktor, salah satunya adalah kurangnya percaya diri. 
Berdasarkan wawancara yang peneliti lakukan terhadap guru BK (Bimbingan dan Konseling) di SMAN 1 Tanjung Mutiara Kabupaten Agam pada bulan April 2021, diperoleh informasi bahwa sebagian besar peserta didik belum bisa berkomunikasi yang baik di lingkungan sekolah. Peserta didik tidak menyampaikan pendapatnya saat diskusi walaupun memiliki ide dan gagasan, sebagian besar peserta didik tidak peduli ucapannya menyinggung perasaan orang lain, peserta didik tidak memberikan ucapan selamat pada temannya yang meraih prestasi, peserta didik masih ada yang belum bisa bersosialisasi dengan orang baru, peserta didik masih memilih teman misalnya memilih berdiskusi dengan teman yang memiliki prestasi lebih tinggi, peserta didik belum bisa mengerjakan tugas tanpa bantuan teman yang lain, peserta didik sulit untuk bekerjasama dalam belajar kelompok, peserta didik tidak bisa mengembangkan keterampilan yang sudah ada dalam dirinya.

Peneliti juga melakukan observasi terhadap peserta didik kelas XI IPA di SMAN 1 Tanjung Mutiara Kabupaten Agam pada bulan April 2021, diperoleh informasi bahwa kesulitan peserta didik untuk mengembangkan kemampuan komunikasi interpersonal dapat menghambat kegiatan-kegiatan belajar dan berdampak terhadap prestasi belajar peserta didik di sekolah. Karna peserta didik kurang percaya diri dan masih malu untuk bertanya tentang hal yang tidak dimengerti, serta peserta didik mengalami prestasi yang menurun.

\section{METODE PENELITIAN}

Penelitian ini termasuk kedalam penelitian deskriptif kuantitatif. Menurut Hermawan (2017:5) penelitian kuantitatif merupakan suatu pendekatan penelitian yang bersifat objektif, dimana hal tersebut mencakup pengumpulan dan analisis data kuantitatif serta menggunakan metode pengujian statistik. Menurut Suryani (2016:109) Penelitian kuantitatif merupakan penelitian yang menggunakan analisis data yang berbentuk angka/numerik. Pendekatan ini lebih menggambarkan data melalui angka-angka, seperti persentasi tingkat pengangguran, kemiskinan, data rasio keuangan, dan lainnya.

Jenis data dalam peneltitian ini yaitu data interval langsung, diperoleh dari responden sebagai objek penelitian melalui kuesioner. Populasi penelitian berjumlah 134 peserta didik. Teknik pengambilan sampel proportional random sampling dengan jumlah sampel sebanyak 57 peserta didik.

Menurut Yusuf (2007:203) proportional random sampling merupakan teknik 
pengambilan sampel yang bertujuan agar jumlah sampel pada masing-masing tingkat sebanding dengan jumlah anggota populasi pada masing-masing stratum populasi.

Berdasarkan hasil penelitian yang telah dilakukan tentang pengaruh komunikasi interpersonal terhadap prestasi belajar peserta didik kelas XI IPA di SMA N 1 Tanjung Mutiara Kabupaten Agam secara umum terungkap bahwa adanya pengaruh yang signifikan dan positif sebesar $11,9 \%$.

\section{PEMBAHASAN}

Berdasarkan variabel penelitian, pada deskripsi hasil penelitian ini akan dibahas tentang komunikasi Interpersonal dan prestasi belajar peserta didik kelas XI IPA di SMA Negeri 1 Tanjung Mutiara Kabupaten Agam, yaitu:

\section{Komunikasi Interpersonal}

Berdasarkan hasil pengolahan data tentang komunikasi interpersonal peserta didik kelas XI IPA di SMA Negeri 1 Tanjung Mutiara Kabupaten Agam terungkap bahwa tidak ada seorang pun peserta didik yang berada pada kategori sangat kurang baik dan pada kategori kurang baik, selanjutnya ada 9 peserta didik $(15,79 \%)$ berada pada kategori cukup baik, lalu ada 40 peserta didik $(70,18 \%)$ berada pada kategori baik, dan ada 8 peserta didik $(14,04 \%)$ berada pada kategori sangat baik. Jadi dapat disimpulkan dari hasil penelitian terlihat sebagian besar peserta didik memiliki komunikasi interpersonal yang baik.

Menurut Devito (2011:252) komunikasi interpersonal adalah proses penyampaian pesan dari penyampai pesan kepada satu orang penerima pesan atau sekolompok orang dengan berbagai dampak dan peluang umpan baliknya. Dalam berkomunikasi masingmasing peserta komunikasi saling bertukar pesan yang menimbulkan dampak perubahan perilaku sebagai akibat dari peluang umpan balik yang diberikan.

Menurut Sapril (2011:7) komunikasi interpersonal secara umum adalah komunikasi antara orang-orang secara tatap muka, masing-masing orang yang terlibat dalam komunikasi tersebut saling mempengaruhi persepsi lawan komunikasinya. Bentuk khusus komunikasi interpersonal adalah komunikasi diadik. 
Hasil penelitian berdasarkan sub variabel:

\section{a. Keterbukaan}

Berdasarkan hasil penelitian tentang komunikasi interpersonal peserta didik kelas XI IPA di SMA Negeri 1 Tanjung Mutiara Kabupaten Agam dilihat dari indikator keterbukaan terungkap bahwa dari 57 peserta didik, tidak ada seorang pun peserta didik yang berada pada kategori keterbukaan sangat kurang baik, kemudian tidak ada peserta didik berada pada kategori kurang baik, selanjutnya ada 17 peserta didik $(29,82 \%)$ berada pada kategori cukup baik, lalu ada 31 peserta didik $(54,39 \%)$ berada pada kategori baik, dan 9 peserta didik (15.79\%) berada pada kategori sangat baik. Jadi dapat disimpulkan dari hasil penelitian sebagian besar keterbukaan pada peserta didik berada pada kategori baik.

Menurut Devito (2011:285) keterbukaan mengacu pada sedikitnya tiga aspek pada komunikasi interpersonal. Pertama komunikator interpersonal harus terbuka kepada orang yang diajaknya berinteraksi. Kedua mengacu pada kesediaan komunikator untuk berinteraksi secara jujur terhadap stimulus yang datang. Ketiga menyangkut "kepemilikan" perasaan dan pikiran. Terbuka dalam pengertian ini adalah mengakui bahwa perasaan dan pikiran yang dilontarkan adalah memang milik anda dan anda bertanggungjawab atasnya.

Menurut Weningtyas (2012:19) keterbukaan yaitu kesediaan untuk membuka diri dalam mengungkapkan informasi secara jujur sesuai dengan keadaan yang sebenarnya dalam berinteraksi.

\section{b. Empati}

Dari hasil pengolahan data komunikasi interpersonal pada peserta didik kelas XI IPA di SMA Negeri 1 Tanjung Mutiara Kabupaten Agam dilihat dari indikator empati terungkap bahwa dari 57 peserta didik, tidak ada seorang pun peserta didik yang berada pada kategori sangat kurang baik dan kurang baik, selanjutnya ada 7 peserta didik $(12,28 \%)$ berada pada kategori cukup baik, lalu ada 34 peserta didik $(59,65 \%)$ berada pada kategori baik, dan 16 peserta didik $(28,07 \%)$ berada pada kategori sangat baik. Dari hasil penelitian dapat disimpulkan sebagian besar empati pada peserta didik berada pada kategori baik.

Menurut Devito (2011:285) empati sebagai kemampuan seseorang untuk 
mengetahui apa yang sedang dialami orang lain pada suatu saat tertentu, dari sudut pandang orang lain itu. Empati dipihak lain adalah merasakan bagi orang lain atau merasa takut bersedih.

Menurut Weningtyas (2012:19) empati yaitu kemampuan seseorang mengetahui apa yang sedang dialami orang lain pada saat tertentu, dari sudut pandang orang lain, melalui kaca mata orang lain.

\section{c. Dukungan}

Dari hasil penelitian tentang komunikasi interpersonal pada peserta didik kelas XI IPA di SMA Negeri 1 Tanjung Mutiara Kabupaten Agam dilihat dari indikator dukungan terungkap bahwa dari 57 peserta didik, tidak ada seorang pun peserta didik yang berada pada kategori sangat kurang baik dan kurang baik, selanjutnya ada 6 peserta didik $(10,53 \%)$ berada pada kategori cukup baik, lalu 29 peserta didik $(50,88 \%)$ berada pada kategori baik, dan 22 peserta didik $(38,60 \%)$ berada pada kategori sangat baik. Jadi dari hasil penelitian dapat disimpulkan sebagian besar dukungan pada peserta didik berada pada kategori baik.

Sikap mendukung, dalam hubungan interpersonal yang efektif terdapat sikap mendukung. Komunikasi yang terbuka dan empatik tidak dapat berlangsung dalam suasana yang tidak mendukung (Devito, 2011:288). Kita memperlihatkan sikap mendukung dengan bersikap (a) deskriptif, bukan evaluative, (b) spontan, bukan strategis, dan (c) provisional, bukan sangat yakin.

Menurut Weningtyas (2012:19) dukungan meliputi tiga hal. Pertama, deskripsi yaitu suasana yang bersifat deskriptif dan bukan evaluatif membantu terciptanya sikap mendukung. Kedua, spontan yaitu kemampuan seseorang untuk berkomunikasi secara spontan dan terus terang yang mempunyai sikap terbuka dalam menyampaikan pemikirannya. Ketiga, provisionalisme dipahami sebagai kemampuan untuk berpikir secara terbuka.

\section{d. Rasa Positif}

Dari hasil pengolahan data komunikasi interpersonal pada peserta didik kelas XI IPA di SMA Negeri 1 Tanjung Mutiara Kabupaten Agam dilihat dari indikator rasa positif terungkap bahwa dari 57 peserta didik, ada 1 peserta didik $(1,75 \%)$ yang berada pada kategori sangat kurang baik, kemudian 21 peserta didik $(36,84 \%)$ berada 
pada kategori kurang baik, selanjutnya 35 peserta didik $(61,40 \%)$ berada pada kategori cukup baik, lalu tidak ada peserta didik berada pada kategori baik dan sangat baik. Jadi dari hasil penelitian dapat disimpulkan sebagian besar rasa positif pada peserta didik berada pada katogori cukup baik.

Menurut Devito (2011:285) sikap positif adalah merupakan kecenderungan seseorang untuk mampu bertindak berdasarkan penilaian yang baik tanpa merasa bersalah yang berlebihan, menerima diri sebagai orang yang penting dan bernilai bagi orang lain, memiliki keyakinan atas kemampuanya untuk mengatasi persoalan, peka terhadap kebutuhan orang lain, pada kebiasaan sosial yang telah diterima.

Menurut Weningtyas (2012:19) rasa positif yaitu kemampuan seseorang dalam memandang dirinya secara positif dan berperasaan positif pada saat berkomunikasi.

\section{e. Kesetaraan}

Dari hasil penelitian tentang komunikasi interpersonal pada peserta didik kelas XI IPA di SMA Negeri 1 Tanjung Mutiara Kabupaten Agam dilihat dari indikator kesetaraan terungkap bahwa dari 57 peserta didik, tidak ada peserta didik yang berada pada kategori sangat kurang baik, kemudian 1 peserta didik $(1,75 \%)$ berada pada kategori kurang baik, selanjutnya 8 peserta didik $(14,04 \%)$ berada pada kategori cukup baik, lalu 40 peserta didik $(70,18 \%)$ berada pada kategori baik, dan 8 peserta didik $(14,04 \%)$ berada pada kategori sangat baik. Jadi dari hasil penelitian dapat disimpulkan sebagian besar kesetaraan pada peserta didik berada pada kategori baik.

Menurut Rakhmat (2004:135) mengemukakan bahwa persamaan merupakan sikap yang tidak mempertegas perbedaan dalam berkomunikasi melainkan mengkomunikasikan penghargaan dan rasa hormat terhadap perbedaan pandangan dan keyakinan.

Menurut Weningtyas (2012:19) komunikasi interpersonal akan efektif apabila suasananya setara, artinya harus ada pengakuan dari kedua belah pihak samasama bernilai dan berharga dan ada sesuatu yang penting untuk disumbangkan. 


\section{Prestasi Belajar}

Berdasarkan hasil pengolahan data prestasi belajar pada peserta didik kelas XI IPA di SMA Negeri 1 Tanjung Mutiara Kabupaten Agam, bahwa dari 57 peserta didik, tidak ada peserta didik yang berada pada kategori sangat rendah dan rendah, selanjutnya ada 25 peserta didik $(43,86 \%)$ berada pada kategori cukup tinggi, lalu tidak ada peserta didik berada pada kategori tinggi, dan ada 32 peserta didik $(56,14 \%)$ berada pada kategori sangat tinggi. Jadi dari hasil penelitian dapat disimpulkan sebagian besar prestasi belajar pada peserta didik berada pada kategori sangat tinggi.

Menurut Aziz (2018:8) prestasi belajar memiliki kata majemuk yang terdiri dari dua kata yakni prestasi dan belajar. Prestasi belajar ini merupakan salah satu alat ukur tingkat keberhasilan seorang peserta didik di dalam kegiatan proses belajar mengajar yang diikutinya selama di sekolah.

Menurut Thaib (2013:387) prestasi belajar merupakan hasil kegiatan belajar, yaitu sejauh mana peserta didik menguasai bahan pelajaran yang diajarkan, yang diikuti oleh munculnya perasaan puas bahwa ia telah melakukan sesuatu dengan baik. Hasil penelitian berdasarkan sub variabel:

\section{a. Kognitif}

Dari hasil penelitian tentang prestasi belajar pada peserta didik kelas XI IPA di SMA Negeri 1 Tanjung Mutiara Kabupaten Agam dilihat dari indikator kognitif, tidak ada peserta didik yang berada pada kategori sangat rendah, ada 2 peserta didik $(3,51 \%)$ berada pada kategori rendah, selanjutnya 39 peserta didik $(68,42 \%)$ berada pada kategori cukup tinggi, lalu ada 15 peserta didik $(26,32 \%)$ berada pada kategori tinggi, dan 1 peserta didik $(1,75 \%)$ berada pada kategori sangat tinggi. Dari hasil penelitian dapat disimpulkan sebagian besar kognitif pada peserta didik berada pada kategori cukup tinggi.

Menurut Syafi'i, dkk (2018:118-120) Aspek kognitif sebagai indikator dalam pencapaian sebuah prestasi, untuk mengukur prestasi peserta didik bidang kognitif ini dapat dilakukan dengan berbagai cara, baik dengan tes tulis maupun tes lisan. Prestasi belajar dalam tingkatan ini merupakan prestasi belajar yang tertinggi dalam ranah kognitif, sehingga memerlukan tipe hasil belajar yang lebih tinggi dari tingkatan sebelumnya (pengetahuan, pemahaman, aplikasi, analisis, sintesis). 
Menurut Waryani (2021:35-36) kategori prestasi belajar ranah kognitif meliputi :

1) Pengetahuan, pengetahuan didefinisikan sebagai mengingat materi pelajaran yang telah disampaikan sebelumnya.

2) Komprehensif, komprehensif didefinisikan sebagai kemampuan untuk memahami makna materi pelajaran.

3) Penerapan, penerapan menunjuk kepada kemampuan menggunakan materi pelajaran pada situasi kongkrit dan situasi baru.

4) Analisis, analisis menunjuk kepada kemampuan untuk menjabarkan materi pelajaran menjadi bagian-bagian kecil sehingga struktur pengorganisasiannya memungkinkan untuk lebih dipahami.

5) Sintesis, sintesis menunjuk kepada kemampuan untuk menempatkan bagian-bagian pengetahuan secara bersama-sama sehingga membentuk suatu kesatuan yang baru.

6) Evaluasi, evaluasi memusatkan pada kemampuan untuk memberikan penilaian atas materi pelajaran.

\section{b. Afektif}

Dari hasil pengolahan data prestasi belajar pada peserta didik kelas XI IPA di SMA Negeri 1 Tanjung Mutiara Kabupaten Agam dilihat dari indikator afektif, tidak ada peserta didik yang berada pada kategori sangat rendah dan rendah, selanjutnya ada 15 peserta didik $(26,32 \%)$ berada pada kategori cukup tinggi, lalu 39 peserta didik $(68,42 \%)$ berada pada kategori tinggi, dan 3 peserta didik $(5,26 \%)$ berada pada kategori sangat tinggi. Jadi dari hasil penelitian dapat disimpulkan sebagian besar afektif pada peserta didik berada pada kategori tinggi.

Menurut Syafi'i, dkk (2018:118-120) aspek afektif ialah ranah berfikir yang meliputi watak perilaku seperti perasaan, minat, sikap, emosi, atau nilai. Ranah afektif menentukan keberhasilan belajar seseorang, orang yang tidak memiliki minat pada pelajaran tertentu sulit untuk mencapai keberhasilan studi secara optimal.

Menurut Waryani (2021:36) kategori prestasi belajar pada ranah afektif meliputi :

1) Penerimaan. Penerimaan merujuk pada kesadaran peserta didik untuk berperan serta dalam suatu peristiwa atau rangsangan. 
2) Menanggapi. Menanggapi menunjuk kepada peran serta aktif dalam kegiatan belajar.

3) Menilai. Menilai berkaitan dengan nilai peran serta siswa di dalam suatu objek, peristiwa atau perilaku.

4) Pengorganisasian. Pengorganisasian berkaitan dengan merangkai berbagai nilai yang berbeda secara bersama-sama, memecahkan permasalahan antara nilai, serta memulai mengembangkan sistem nilai yang terpadu.

5) Perwatakan nilai. Pada jenjang ini, seseorang memiliki sistem nilai yang akan mengontrol perilaku untuk periode tertentu dalam pengembangan pola kepribadiannya.

\section{c. Psikomotor}

Dari hasil pengolahan data prestasi belajar pada peserta didik kelas XI IPA di SMA Negeri 1 Tanjung Mutiara Kabupaten Agam dilihat dari indikator psikomotor terungkap bahwa dari 57 peserta didik, tidak ada peserta didik yang berada pada kategori sangat rendah, kemudian ada 1 peserta didik (1,75\%) berada pada kategori rendah, selanjutnya ada 15 peserta didik $(26,32 \%)$ berada pada kategori cukup tinggi, lalu 33 peserta didik $(57,89 \%)$ berada pada kategori tinggi, dan 8 peserta didik $(14,04 \%)$ berada pada kategori sangat tinggi. Jadi dari hasil penelitian dapat disimpulkan sebagian besar psikomotorik pada peserta didik berada pada kategori tinggi.

Menurut Syafi'i, dkk (2018:118-120) Psikomotorik merupakan aspek yang berhubungan dengan olah gerak seperti yang berhubungan dengan otot-otot syaraf.

Menurut Waryani (2021:37) kategori pretasi belajar pada ranah psikomotor meliputi :

1) Persepsi. Jenjang pertama ini berkaitan dengan penggunaan bagian-bagian tubuh dalam suatu aktivitas.

2) Menata. Menata menunjuk kepada kesiapan untuk melakukan suatu tindakan.

3) Tanggapan yang terarah. Tanggapan yang terarah berkaitan dengan tahap awal di dalam berbagai jenis keterampilan yang meliputi imitasi atau pengulangan tindakan dan uji coba. 
4) Mekanisme. Mekanisme berkaitan dengan tindakan yang diarahkan untuk menjadi perilaku kebiasaan.

5) Tanggapan terbuka. Tanggapan terbuka yang bersifat kompleks menunjuk kepada keterampilan melakukan suatu tindakan yang telah memiliki pola tertentu.

6) Adaptasi. Adaptasi berkaitan dengan keterampilan yang telah dikembangkan secara baik atau seseorang dapat melakukan modifikasi terhadap pola yang telah ada.

7) Keaslian. Keaslian menunjuk kepada penciptaan pola perilaku yang baru untuk menanggapi suatu situasi atau permasalahan baru.

\section{Pengaruh Komunikasi Interpersonal Terhadap Prestasi Belajar}

Berdasarkan hasil penelitian menunjukkan arah regresi antara variabel komunikasi interpersonal terhadap prestasi belajar pada peserta didik kelas XI IPA SMA Negeri 1 Tanjung Mutiara Kabupaten Agam dapat digambarkan bahwa diperoleh arah regresi antara variabel komunikasi interpersonal terhadap prestasi belajar menghasilkan koefisien pada table 22 sebesar 0,306 dan konstanta sebesar 102,149. Dengan demikian, bentuk pengaruh antara kedua variabel tersebut dapat dinyatakan oleh persamaan regresi $\hat{y}=102,149+0,306$ X. Kemudian nilai sig 0,000<0,05 yang berarti Ho ditolak dan Ha diterima. Jadi besarnya pengaruh yang diberikan oleh komunikasi interpersonal terhadap prestasi belajar berdasarkan uji regresi sebesar 0,119 x $100 \%$ atau $11,9 \%$. Hal ini menunjukkan bahwa sumbangan pengaruh komunikasi interpersonal terhadap prestasi belajar peserta didik sebesar $11,9 \%$. Sedangkan sisanya sebesar $88,1 \%$ dipengaruhi oleh faktor yang tidak dimasukkan dalam penelitian ini.

Menurut Fitria (2014:2) kemampuan komunikasi interpersonal yang merupakan faktor internal juga mempengaruhi proses dan prestasi belajar peserta didik. Proses belajar mengajar akan senantiasa merupakan kegiatan interaksi yang berpangkal pada komunikasi yang berarti menjadikan milik bersama yakni peserta didik sebagai pihak yang belajar dan guru sebagai subjek pokoknya. Dalam hal ini kemampuan komunikasi interpersonal peserta didikakan tampak yaitu menunjukkan reaksi sosial yang berbedabeda. Ada peserta didik yang muda bergaul, ada pula peserta didik yang sulit untuk untuk 
bersosialisasi, kesulitan bersosialisasi dapat disebabkan oleh beberapa faktor, salah satunya adalah kurangnya percaya diri.

Menurut Utami (2016:7) komunikasi interpersonal dianggap penting dalam upaya mengubah sikap, pendapat atau perilaku seseorang karena sifatnya dialog berupa percakapan. Keefektifan komunikasi interpersonal dipengaruhi oleh unsur-unsur kesamaan, keterbukaan, sikap positif dan rasa simpati. Kemampuan komunikasi yang harus dikuasai adalah keterampilan mendengarkan efektif, keterampilan publik speaking dan keterampilan menulis secara efektif. Dan keterampilan yang harus dikuasai yaitu kemampuan komunikasi interpersonal karna didalam proses belajar mengajar merupakan suatu interaksi antara peserta didik dan guru, peserta didik dengan peserta didik, kemampuan komunikasi akan berpengaruh terhadap prestasi belajar.

\section{KESIMPULAN}

Berdasarkan hasil penelitian tentang pengaruh komunikasi interpersonal terhadap prestasi belajar peserta didik kelas XI IPA di SMA Negeri 1 Tanjung Mutiara Kabupaten Agam dapat diambil kesimpulan sebagai berikut.

1. Komunikasi interpersonal pada peserta didik kelas XI IPA SMA Negeri 1 Tanjung Mutiara Kabupaten Agam berada pada kategori baik.

2. Prestasi belajar peserta didik kelas XI IPA SMA Negeri 1 Tanjung Mutiara Kabupaten Agam berada pada kategori sangat tinggi.

3. Terdapat pengaruh yang signifikan dan positif komunikasi interpersonal terhadap prestasi belajar peserta didik kelas XI IPA di SMA Negeri 1 Tanjung Mutiara Kabupaten Agam.

\section{DAFTAR PUSTAKA}

Aziz. 2018. Kontribusi Lingkungan Belajar dan Proses Pembelajaran Terhadap Prestasi Belajar Siswa di Sekolah. Jurnal Tarbiyah. Vol 25. No 2. Hal 7-8.

Devito, Joseph A. 2011. Komunikasi Antar Manusia. Tanggerang Selatan. Kharisma Publishing Group.

Fitria, Awaludin. (2014). Pengaruh kemampuan komunikasi interpersonal Terhadap prestasi belajar matematika siswa SMP Kemala Bhayangkari 1 Medan tahun ajaran 2014/2015. Jurnal Mantik Penusa. Vol 15. No 1. Hal 2. 
Hamdu, Ghullam, dkk. (2011). Pengaruh motivasi belajar siswa terhadap prestasi belajar IPA di sekolah dasar. Jurnal Penelitian Pendidikan. Universitas Pendidikan Indonesia.Vol. 12 No. 1. Hal 83.

Hermawan, A dan Husna L. 2017. Penelitian Bisnis Pendekatan Kuantitaif. Jakarta: Kencana.

Mulyana, Deddy. 2000. Ilmu Komunikasi: Suatu Pengantar. Bandung: Remaja Rosdakarya.

Rakhmat, Jalaluddin. 2004. Psikologi Komunikasi. Jakarta: Remaja Rosdakarya.

Suryani dan Hendryadi. 2016. Metode Riset Kuantitatif: Teori dan Aplikasi Pada Penelitian Bidang Manajemen dan Ekonomi Islam. Jakarta: Prenadamedia Group.

Sapril. 2011. Komunikasi Interpersonal Pustakawan. Jurnal Iqra'. Vol 5. No 1. Hal 6-11.

Syafi'i, Ahmad, dkk. 2018. Studi Tentang Prestasi Belajar Siswa dalam Berbagai Aspek dan Faktor yang Mempengaruhi. Jurnal Komunikasi Pendidikan. Vol 2. No 2. Hal 188120.

Thaib, Eva Nauli. 2013. Hubungan Antara Prestasi Belajar Dengan Kecerdasan Emosional. Jurnal Ilmiah Didaktika. Vol XIII. No 2. Hal 384-399.

Utami, Yulia. 2016. Pengaruh Kemampuan Komunikasi Interpersonal Terhadap Prestasi Belajar Matematika Siswa SMP Swasta PGRI 58 Tanjung Morawa. Jurnal Mantik Penusa. Vol 20. No 1. Hal 6-13.

Waryani. 2021. Dinamika Kinerja Guru dan Gaya Belajar. Indramayu: Adanu Abimata.

Weningtyas, Enggarayu, dkk. 2012. Pengaruh Komunikasi Interpersonal dan Kualitas Pelayanan Terhadap Kepuasan Konsumen. Jurnal Psikologika. Vol 17. No 1. Hal $17-$ 26.

Yusuf, Muri. 2007. Metodologi Penelitian. Padang: UNP Press. 